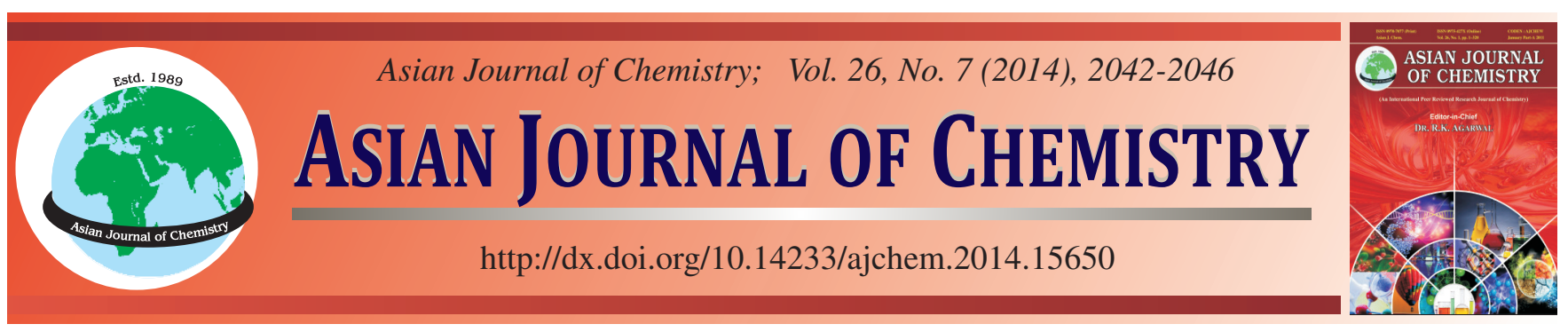

\title{
Study on Producing Iron Ore Concentrate by Removing Sulphur from Pyrite Cinder with Nitric Acid Leaching
}

\author{
ZhaOZHONG ShI ${ }^{*}$, YANXIA HAN and GUIRONG Zhan
}

School of Chemical Engineering, Kaifeng University, Dongjing Road, Kaifeng 475004, Henan Province, P.R. China

*Corresponding author: Tel/Fax: +86 378 3810622/3655979; E-mail: haike1015@sina.com

Pyrite cinder is obtained by roasting the pyrite at $700-800{ }^{\circ} \mathrm{C}$, so activity of the iron oxides is weak. Based on its weak activity property, nitric acid extraction of pyrite cinder is first used to remove the impurities such as $\mathrm{S}, \mathrm{CaO}$ and $\mathrm{Al}_{2} \mathrm{O}_{3}$ and meanwhile, less than $10 \%$ of the iron is dissolved into liquid. Most iron is enriched into acid leaching residue and the liquid are to be treated further. Orthogonal test shows that the optimal condition for leaching the cinder is concentration $5 \mathrm{~mol} \mathrm{~L}^{-1}$, the time is $1 \mathrm{~h}$, temperature $50{ }^{\circ} \mathrm{C}$ and excess coefficient is 15 . By this time, desulphurization degree is over $99 \%$, and iron leaching rate is less than $10 \%$. In the optimal technical condition, the sulphur content of pyrite cinder leaching slag is $0.03 \%$. It is in line with iron ore concentrate requirements (sulphur content is less than $0.10 \%$ ). To reveal the mechanism of this process, the phase transformation of the process were studied by X-ray diffractometer.

Keywords: Pyrite cinder, Nitric acid, Orthogonal array experiment, Leaching.

ᄂ - - - - - - - - - - - - - - - - - - - - - - - - -

\section{INTRODUCTION}

Pyrite cinder is the residual of the production of sulphuric acid from pyrite, which mainly contains iron oxide $\left(\mathrm{Fe}_{2} \mathrm{O}_{3}\right.$ and $\left.\mathrm{Fe}_{3} \mathrm{O}_{4}\right)$. A great deal of pyrite cinder has been produced in the world. For example, in China the average annual production of pyrite cinder is more than 20 million tons ${ }^{1}$. However, pyrite cinder has been rarely used directly as the raw materials for high-sulphur content and other impurities. The utilization of pyrite cinder generally involves producing of building material directly ${ }^{2,3}$ the preparation of pigments ${ }^{4}$, water purification materials ${ }^{5}$ sponge iron powder ${ }^{6}$ and ferrous sulfate ${ }^{7}$. All these were lower added value products.

If pyrite cinder can be used to produce high quality of iron oxide concentrate, a great increase in its added value will be achieved. In addition, with the continuous exhaustion of mineral resources, iron ore resources in China become increasingly scarce ${ }^{8}$. Therefore, the recovery and utilization of iron in pyrite cinder have become increasingly important to save iron resources from now on.

Recently, many physical process have been studied to recover iron oxide concentrate through magnetizing roasting, gravity separation or froth flotation ${ }^{9}$. However, a major drawback of the magnetizing roasting method is energy-intensive and not sufficiently flexible ${ }^{10}$. A process for recovering of iron oxide concentrate from pyrite cinder with alkali solution and aqua regia solution ${ }^{11}$ has been reported. Although the sulphur content of pyrite cinder was reduced evidently, a large of acid leaching solution is not easy to be treated completely in industry.

The aim of this work is to state an economical and environmentally acceptable way to recover iron oxide concentrate from high-sulphur pyrite cinder by leaching process with nitric acid. Herein, orthogonal experiments were performed to optimize the leaching conditions of pyrite cinder and the feasibility of acid leaching reaction was analyzed from the thermodynamic point of view.

\section{EXPERIMENTAL}

Pyrite cinder was supplied by Anhui Tongling Chemical Industry Co. The chemical composition results of raw material were shown in Table-1. Particle size of the original material was performed by laser particle analyzer with the results revealing that $80 \%$ of the sample being finer than $125 \mu \mathrm{m}$ (Table-2). This fine size distribution indicated that physical concentration methods, such as gravity or magnetic separation, were not suitable to treat such a material. Further, hydrometallurgical reaction kinetics involving this waste should be fast, due to the prevailing fine particle sizes ${ }^{12}$. The crystalline phases were investigated by powder XRD technique (Fig. 1). Hematite, magnetite, quartz and bassinite were identified to be the main phases of raw material, moreover, bassanite was the source of sulphur . 


\begin{tabular}{cccccccc}
\hline \multicolumn{7}{c}{ TABLE-1 } \\
\multicolumn{10}{c}{ CHEMICAL COMPOSITION OF RAW MATERIAL } \\
\hline Components & $\mathrm{Fe}$ & $\mathrm{CaO}$ & $\mathrm{Al}_{2} \mathrm{O}_{3}$ & $\mathrm{~S}$ & $\mathrm{SiO}_{2}$ & $\mathrm{MgO}$ \\
Wt $\%$ & 48.94 & 5.35 & 1.35 & 3.17 & 8.90 & 1.35 \\
\hline
\end{tabular}

\begin{tabular}{|c|c|c|c|c|c|}
\hline \multicolumn{6}{|c|}{$\begin{array}{c}\text { TABLE-2 } \\
\text { SIZE DISTRIBUTION OF PYRITE CINDER }\end{array}$} \\
\hline Particle size $(\mu \mathrm{m})$ & $>0.300$ & $0.300-0.200$ & $0.200-0.125$ & $0.125-0.075$ & $<0.075$ \\
\hline wt $\%$ & 0.66 & 3.80 & 13.69 & 58.19 & 23.66 \\
\hline
\end{tabular}

Nitric acid (AR, $65 \%$ ), hydrochloric acid (AR, 36.5\%), stannous chloride (AR), methyl orange (AR) and diphenylamine sulphuric acid sodium salt (AR) was purchased from Sinopharm Chemical Reagent Co. Ltd. (China). Phosphorus mixture was prepared by dumping $150 \mathrm{~mL}$ of concentrated sulphuric acid into $700 \mathrm{~mL}$ of deionized water and then mixing with $150 \mathrm{~mL}$ of phosphoric acid after cooling.



Fig.1. XRD of original pyrite cinder

Treatment of pyrite cinder: To reuse the pyrite cinder, $30 \mathrm{~g}$ of pyrite cinder was added into a $250 \mathrm{~mL}$ three-necked bottle followed by the addition of nitric acid. The reaction was allowed at designed temperature under a stirring speed of $400 \mathrm{rpm}$. Then the reactants were collected by filtration and washing with deionized water for three times. The residuals were dried for $2 \mathrm{~h}$ at $110 \pm 2{ }^{\circ} \mathrm{C}$ and then weighted. The desulphurization rate (DSR) was calculated according to the following equation:

$$
\operatorname{DSR}(\%)=\frac{\mathrm{m}_{1} \times \mathrm{S}_{1} \%-\mathrm{m}_{2} \times \mathrm{S}_{2}^{\prime} \%}{\mathrm{~m}_{1} \times \mathrm{S}_{1} \%} \times 100
$$

where $\mathrm{m}_{1}$ is the weight of feed pyrite cinder $(\mathrm{g}) ; \mathrm{S}_{1} \%$ is the weight fraction of iron in pyrite cinder; $\mathrm{m}^{2}$ is the weight of residual solid after reacting with nitric acid (g); $\mathrm{S}_{2} \%$ is the weight fraction of iron in the residual solid. And mean while, the iron enrichment degree (EFD was calculated according to the following equation ${ }^{13}$.

$$
\mathrm{EFD} \%=1-\left(\frac{\mathrm{m}_{1} \times \mathrm{Fe}_{1} \%-\mathrm{m}_{2} \times \mathrm{Fe}_{2} \%}{\mathrm{~m}_{1} \times \mathrm{Fe}_{1} \%}\right)
$$

where $\mathrm{m}_{1}$ is the weight of feed pyrite cinder $(\mathrm{g}) ; \mathrm{Fe}_{1} \%$ is the weight fraction of iron in pyrite cinder; $\mathrm{m}_{2}$ is the weight of residual solid after reacting with nitric acid ( $\mathrm{g}$ ); $\mathrm{Fe}_{2} \%$ is the weight fraction of iron in the residual solid.
Determination of weight fraction of iron: Pyrite cinder $(1 \mathrm{~g})$ was accurately weighted and placed in a $250 \mathrm{~mL}$ beaker followed by $20 \mathrm{~mL}$ of concentrated hydrochloric acid. The pyrite cinder was heated to boiling and kept for $1 \mathrm{~min}$. The solution was transferred to a $250 \mathrm{~mL}$ volumetric flask after cooling to ambient. Then $25 \mathrm{~mL}$ of the prepared solution was transferred into a $250 \mathrm{~mL}$ conical flask followed by the addition of $8 \mathrm{~mL}$ of concentrated hydrochloric acid. Afterward, the solution was also heated to boiling and 6 drops of methyl orange was added. Then stannous chloride was slowly added dropwise. During this process, the conical flask was shaken severely. When redness of the solution exactly fades, the conical flask was cooled rapidly. After that, $50 \mathrm{~mL}$ of deionized water and $20 \mathrm{~mL}$ of phosphorus mixture were added. At the end, the mixture was titrated by $0.05 \mathrm{M} \mathrm{K}_{2} \mathrm{Cr}_{2} \mathrm{O}_{7}$ to stable fuchsia as terminal point using diphenylamine sulphuric acid sodium salt as the indicator.

Determination of nitric acid amount: The reaction for removing sulphur by leaching pyrite cinder with nitric acid are as follows:

$$
\begin{gathered}
\mathrm{CaSO}_{4}+2 \mathrm{HNO}_{3}=\mathrm{Ca}\left(\mathrm{NO}_{3}\right)_{2}+\mathrm{H}_{2} \mathrm{SO}_{4} \\
\mathrm{MgO}+2 \mathrm{HNO}_{3}=\mathrm{Mg}\left(\mathrm{NO}_{3}\right)_{2}+\mathrm{H}_{2} \mathrm{O} \\
6 \mathrm{HNO}_{3}+\mathrm{Al}_{2} \mathrm{O}_{3}=2 \mathrm{Al}\left(\mathrm{NO}_{3}\right)_{3}+3 \mathrm{H}_{2} \mathrm{O} \\
6 \mathrm{NNO}_{3}+\mathrm{Fe}_{2} \mathrm{O}_{3}=2 \mathrm{Fe}\left(\mathrm{NO}_{3}\right)_{3}+3 \mathrm{H}_{2} \mathrm{O}
\end{gathered}
$$

According to chemical stoichiometric relation, nitric acid amount is determinated by the following expression.

$$
\mathrm{M}_{\mathrm{HNO}_{3}}=2 \mathrm{M}_{\mathrm{CaSO}_{4}}+3 \mathrm{M}_{\mathrm{Al}_{2} \mathrm{O}_{3}}+2 \mathrm{M}_{\mathrm{MgO}}+\mathrm{aM}_{\text {other }}
$$

In order to eliminate impurities maximum,excessive nitric acid is used in the process of leaching. E is excess coefficient.

$$
\mathrm{E}=\frac{\mathrm{M}_{\mathrm{P}}}{\mathrm{M}_{\mathrm{T}}}
$$

where $M_{P}$ is nitric acid practical quantity; $M_{t}$ is nitric acid theoretical quantity.

\section{RESULTS AND DISCUSSION}

Orthogonal experiments: Leaching of pyrite cinder in nitric acid is a reaction at liquid/solid interface. The main influencing factors include rate of liquid to solid, stirring speed, nitric acid concentration, excess coefficient, reaction temperature and reaction time. The effects of stirring speed and the rate of liquid to solid was investigated systematically ${ }^{14}$, showing the optimized stirring speed is $400 \mathrm{rpm}$. In previous work, it was proposed that the rate of liquid to solid has little influence on the reaction ${ }^{15}$ when it is less than 4 . In the present work, we focused on the effects of nitric acid concentration, excess coefficient, reaction temperature and reaction time. An orthogonal array with four factors in four levels was employed to evaluate each factor and the results are summarized in Table-3. 
It can be observed that the influence of the four factors on desulfurization rate is in the following sequence:reaction time (9.77), nitric acid concentration (8.92), reaction temperature (6.51), excessive coefficient (4.30). The optimized reaction conditions for desulfurization rate are: reaction temperature is $70^{\circ} \mathrm{C}$, reaction time is $2 \mathrm{~h}$, excessive coefficient is 25 and sulphuric acid concentration is $6 \mathrm{~mol} \mathrm{~L}^{-1}$.

Table- 3 indicated also that the influence of the four factors on the iron enrichment degree is as below:reaction time (4.8), nitric acid concentration (4.2), excessive coefficient (0.74), reaction temperature $(0.58)$. The optimized reaction conditions for iron enrichment degree are:reaction temperature is $40{ }^{\circ} \mathrm{C}$, reaction time is $0.5 \mathrm{~h}$, excessive coefficient is 20 , and nitric acid concentration is $3 \mathrm{~mol} \mathrm{~L}^{-1}$.

As a whole, the comparison of desulfurization rate and iron enrichment degree revealed proximately inverse trend when above four experimental parameters. In order to optimize further reaction condition in the process of leaching sulphur, several condition experiments were performed, respectively.

\section{Effects of each factor on disulphurization degree}

Effects of nitric acid concentration on desulfurization rate (DSR) and iron enrichment degree (EFD): The reactions were conducted for different nitric acid concentration of 2.0, 2.5, 3.0, 3.5, 4.0, 4.5, 5.0 and $6.0 \mathrm{~mol} \mathrm{~L}^{-1}$ under the condition of excess coefficient of 25 , time of $1 \mathrm{~h}$ at $60{ }^{\circ} \mathrm{C}$. It could be seen from Fig. 2 that desulfurization rate increases with the nitric acid concentration at the initial

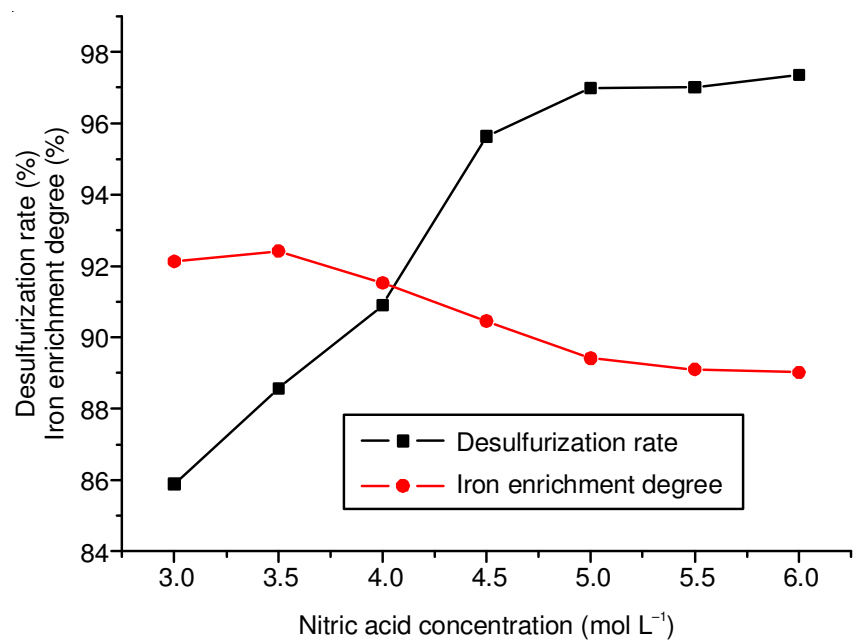

Fig. 2. Effect of nitric acid concentration on desulfurization rate and iron iron enrichment degree

\begin{tabular}{|c|c|c|c|c|c|c|}
\hline \multicolumn{7}{|c|}{$\begin{array}{c}\text { TABLE-3 } \\
\text { RESULTS OF ORTHOGONAL ARRAY EXPERIMENT }\end{array}$} \\
\hline No. & $\mathrm{C}\left(\mathrm{mol} \mathrm{L}^{-1}\right)$ & $\mathrm{t}(\mathrm{h})$ & $\mathrm{T}\left({ }^{\circ} \mathrm{C}\right)$ & E & $\operatorname{DSR}(\%)$ & EFD (\%) \\
\hline 1 & 3.0 & 0.5 & 40 & 10 & 73.09 & 96.08 \\
\hline 2 & 3.0 & 1.0 & 50 & 15 & 82.32 & 95.32 \\
\hline 3 & 3.0 & 1.5 & 60 & 20 & 87.19 & 93.51 \\
\hline 4 & 3.0 & 2.0 & 70 & 25 & 89.97 & 92.44 \\
\hline 5 & 4.0 & 0.5 & 50 & 20 & 80.38 & 93.97 \\
\hline 6 & 4.0 & 1.0 & 40 & 25 & 90.80 & 91.11 \\
\hline 7 & 4.0 & 1.5 & 70 & 10 & 88.63 & 90.76 \\
\hline 8 & 4.0 & 2.0 & 60 & 15 & 91.34 & 88.05 \\
\hline 9 & 5.0 & 0.5 & 60 & 25 & 88.17 & 92.65 \\
\hline 10 & 5.0 & 1.0 & 70 & 20 & 95.64 & 90.83 \\
\hline 11 & 5.0 & 1.5 & 40 & 15 & 90.87 & 90.77 \\
\hline 12 & 5.0 & 2.0 & 50 & 10 & 92.98 & 87.02 \\
\hline 13 & 6.0 & 0.5 & 70 & 15 & 90.01 & 92.52 \\
\hline 14 & 6.0 & 1.0 & 60 & 10 & 95.43 & 90.03 \\
\hline 15 & 6.0 & 1.5 & 50 & 25 & 98.38 & 89.47 \\
\hline 16 & 6.0 & 2.0 & 40 & 20 & 92.43 & 88.54 \\
\hline $\mathrm{K}_{1}$ & 336.57 & 331.65 & 347.19 & 350.13 & & \\
\hline $\mathrm{K}_{2}$ & 350.15 & 359.19 & 354.06 & 354.10 & & \\
\hline $\mathrm{K}_{3}$ & 368.66 & 367.07 & 362.13 & 355.64 & & \\
\hline $\mathrm{K}_{4}$ & 372.25 & 370.72 & 368.25 & 367.32 & & \\
\hline $\mathrm{K}_{1} / 4$ & 84.14 & 82.91 & 85.55 & 87.53 & & \\
\hline $\mathrm{K}_{2} / 4$ & 87.53 & 89.80 & 88.52 & 88.52 & & \\
\hline $\mathrm{K}_{3} / 4$ & 90.92 & 91.77 & 90.53 & 88.91 & & \\
\hline $\mathrm{K}_{4} / 4$ & 93.06 & 92.68 & 92.06 & 91.83 & & \\
\hline $\mathrm{R}$ & 8.92 & 9.77 & 6.51 & 4.30 & & \\
\hline \multicolumn{7}{|c|}{ Sequence of four influencing factor on DSR: $\mathrm{B}>\mathrm{A}>\mathrm{C}>\mathrm{D}$} \\
\hline $\mathrm{K}_{1}$ & 377.35 & 375.22 & 366.50 & 363.89 & & \\
\hline $\mathrm{K}_{2}$ & 364.89 & 367.29 & 365.78 & 366.66 & & \\
\hline $\mathrm{K}_{3}$ & 361.27 & 364.51 & 364.24 & 366.85 & & \\
\hline $\mathrm{K}_{4}$ & 360.56 & 356.02 & 366.55 & 365.67 & & \\
\hline $\mathrm{K}_{1} / 4$ & 94.34 & 93.80 & 91.62 & 90.97 & & \\
\hline $\mathrm{K}_{2} / 4$ & 91.22 & 91.82 & 91.44 & 91.66 & & \\
\hline $\mathrm{K}_{3} / 4$ & 90.32 & 91.13 & 91.06 & 91.71 & & \\
\hline $\mathrm{K}_{4} / 4$ & 90.14 & 89.00 & 91.64 & 91.42 & & \\
\hline $\mathrm{R}$ & 4.2 & 4.8 & 0.58 & 0.74 & & \\
\hline
\end{tabular}


stage and levels off after $5 \mathrm{~mol} \mathrm{~L}^{-1}$. A explanation of the behaviour was that increasing concentration would decrease diffusion rate of reactants. When nitric acid concentration was $5 \mathrm{~mol} \mathrm{~L}{ }^{-1}$, desulfurization rate was $97 \%$. According to the demand of ore iron concentrate, sulphur content is less than $0.1 \%$. If desulfurization rate and iron enrichment degree were considered comprehensively, nitric acid concentration 4.5 mol L-1 was chosen to be optimal.

Effects of reaction time on desulfurization rate and iron enrichment degree: The experimental resuts obtained under a series of different reaction time such as $0.5,1,1.5$, 2.0, 2.5 and $3 \mathrm{~h}$, respectively, were shown in Fig. 3. Other experimental parameters were kept as the following: the condition of excess coefficient of 25 , temperature $60{ }^{\circ} \mathrm{C}$ and nitric acid concentration of $5 \mathrm{~mol} \mathrm{~L}^{-1}$. The results showed that desulfurization rate increased at initial stage, but it tended slowly after $2.5 \mathrm{~h}$. All things considered, reaction time $1.5 \mathrm{~h}$ was more feasible.

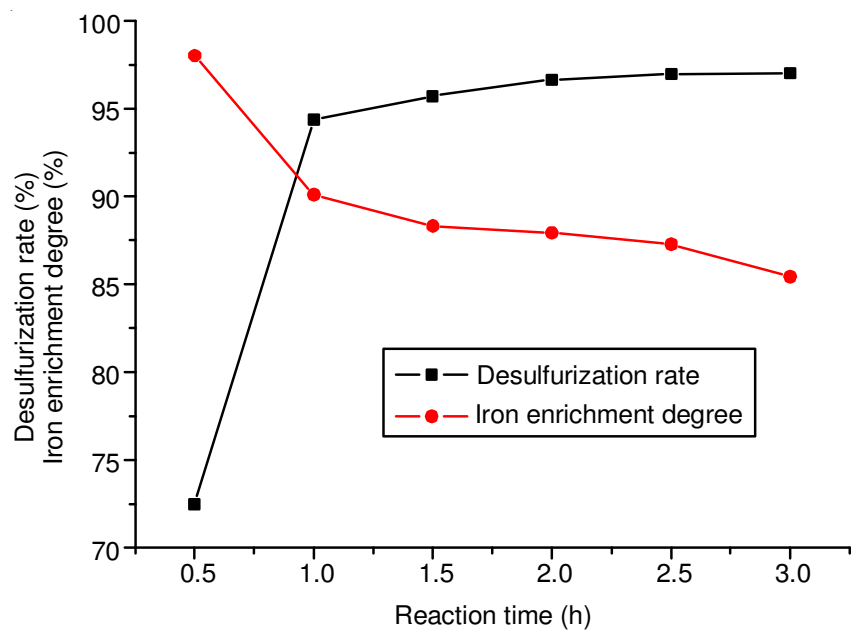

Fig. 3. Effect of time on desulphurization degree and iron enrichment rate

Effects of temperature and excess coefficient on desulfurization rate and iron enrichment degree: Effects of temperature and excess coefficient on desulfurization rate and iron enrichment degree were investigated also and the results were shown in Figs. 4 and 5. It indicated that desulfurization rate was improved as temperature and excess coefficient increased. Overall consideration desulfurization rate and iron enrichment degree, temperature of $60^{\circ} \mathrm{C}$ and excess coefficient of 15 were thought to be preferable.

Based to the above-mentioned reaction conditions, the optimized reaction conditions are: reaction temperature 50 ${ }^{\circ} \mathrm{C}$, reaction time $1 \mathrm{~h}$, excessive coefficient 15 and nitric acid concentration $5 \mathrm{~mol} \mathrm{~L}^{-1}$.

\section{Thermodynamic analysis of disulphurization process}

Main reaction: Sulphur exists in pyrite cinder as the phases of bassanite, and the main reaction of disulphurization was shown below.

$\begin{array}{lllll}\mathrm{CaSO}_{4}+2 \mathrm{HNO}_{3} \rightarrow \mathrm{Ca}\left(\mathrm{NO}_{3}\right)_{2}+\mathrm{H}_{2} \mathrm{SO}_{4} \\ \Delta_{\mathrm{f}} \mathrm{G}_{\mathrm{m}}^{\mathrm{o}}\left(\mathrm{kJ} \mathrm{mol}^{-1}\right)-1320 & -110.58 & -773 & -743 \\ \Delta_{\mathrm{f}} \mathrm{H}_{\mathrm{m}}^{\mathrm{o}}\left(\mathrm{kJ} \mathrm{mol}^{-1}\right)-1432.7 & -206.56 & -956.63 & -908.4 \\ \mathrm{~S}_{\mathrm{m}}^{\mathrm{o}}\left(\mathrm{J} \mathrm{mol}^{-1} \mathrm{~K}^{-1}\right) & 107.0 & 146.0 & 239.51 & 20.06\end{array}$

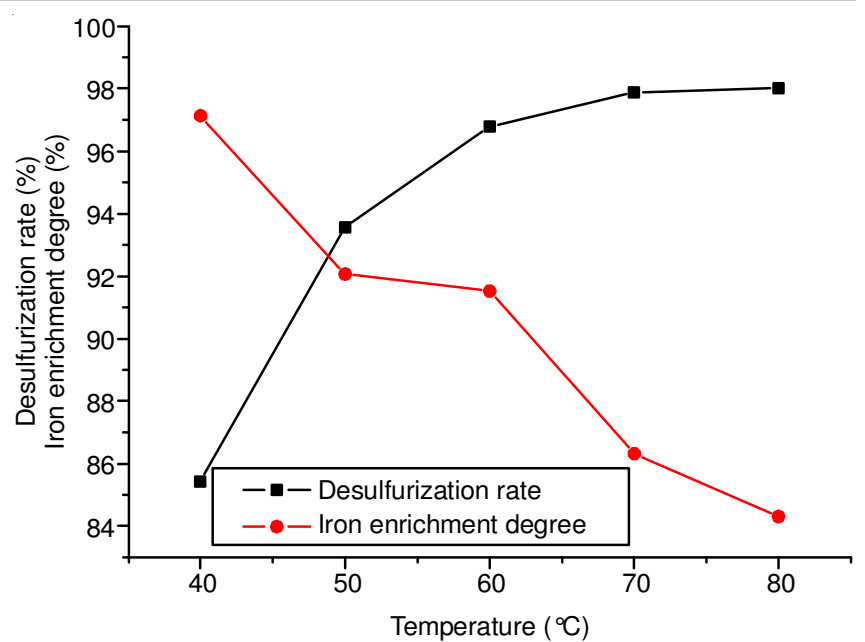

Fig. 4. Effect of temperature on desulphurization rate and iron enrichment degree

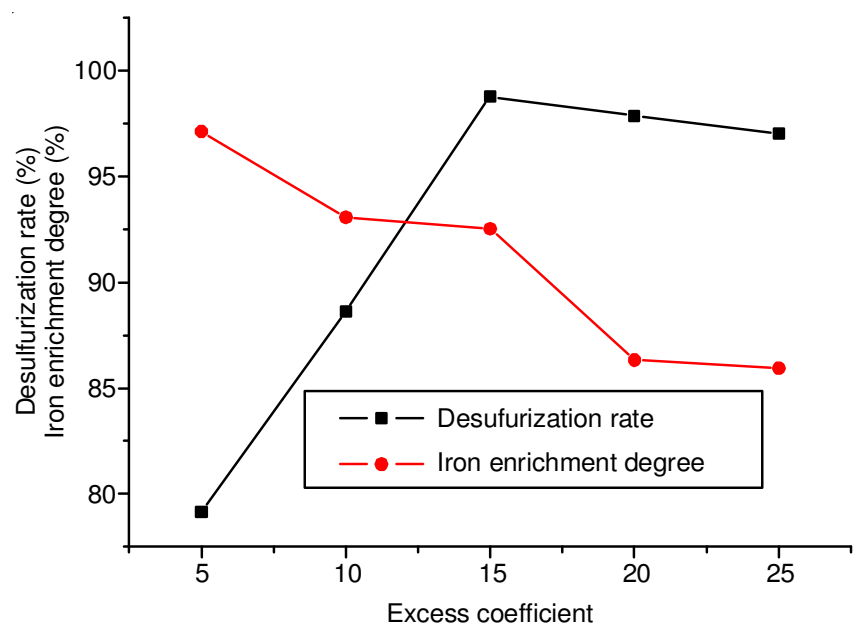

Fig. 5. Effect of nitric acid on desulphurization rate and iron enrichment degree

$$
\begin{array}{r}
\Delta \mathrm{S}_{298}^{\mathrm{o}}=-773-743-2 \times(-110.58)-(-1320) \\
=25.16 \mathrm{~kJ} \mathrm{~mol}^{-1}>0
\end{array}
$$

$\Delta \mathrm{S}_{298}^{\mathrm{o}}>0$ indicated that reaction (I) was not spontaneous under normal temperature.

$$
\begin{gathered}
\begin{aligned}
& \Delta \mathrm{H}_{298}^{\mathrm{o}}=(-908.4)+(-956.63)-2 \times(-206.56)-(-1432.7) \\
&=-19.91 \mathrm{~kJ} \mathrm{~mol}^{-1} \\
& \Delta \mathrm{S}_{298}^{\mathrm{o}}=20.06+239.51-2 \times 146.0-107 \\
&=-139.43 \mathrm{~J} \mathrm{~mol}^{-1} \mathrm{~K}^{-1}
\end{aligned}
\end{gathered}
$$

$\Delta \mathrm{H}_{298}^{\mathrm{o}}<0$ and $\Delta \mathrm{S}_{298}^{\mathrm{o}}<0$ showed that reaction I was spontaneous under lower temperature.

Calculating results as per Gibbs-Helmholtz equation $\Delta_{\mathrm{r}} \mathrm{G}_{\mathrm{m}}^{\mathrm{o}}=\Delta_{\mathrm{r}} \mathrm{H}_{\mathrm{m}}^{\mathrm{o}}-\mathrm{T} \Delta_{\mathrm{r}} \mathrm{S}_{\mathrm{m}}^{\mathrm{o}} \mathrm{T}$ showed that reaction (I) could alternate to be spontaneous when temperature was less than $143 \mathrm{~K}$, but it would not be accomplished in practice.

However, the reaction between nitric acid and bassanite had been proved to be spontaneous via all the above experiments. In view of this, this behavior may be explained as follows. 
TABLE-4

CHEMICAL COMPOSITION OF IRON OXIDE CONCENTRATE

\begin{tabular}{ccccccc}
\hline Components & $\mathrm{Fe}$ & $\mathrm{CaO}$ & $\mathrm{Al}_{2} \mathrm{O}_{3}$ & $\mathrm{~S}$ & $\mathrm{SiO}_{2}$ & $\mathrm{MgO}$ \\
\hline Weight & 61.27 & 0.09 & 0.06 & 0.03 & 9.81 & 0.04 \\
\hline
\end{tabular}

A little iron monoxide in pyrite cinder could react with sulphuric acid.

$$
\mathrm{FeO}+\mathrm{H}_{2} \mathrm{SO}_{4} \rightarrow \mathrm{FeSO}_{4}+\mathrm{H}_{2} \mathrm{O}
$$

$\Delta \mathrm{G}_{\mathrm{m}}^{\mathrm{o}}\left(\mathrm{kJ} \mathrm{mol}^{-1}\right)-251.2-743 \quad-818.53-237$

$\Delta \mathrm{G}_{298}^{\mathrm{o}}=-237-818.53-(-251.2)-(-743)=-61.33 \mathrm{~kJ} \mathrm{~mol}^{-1}$

$\Delta \mathrm{G}_{298}^{\mathrm{o}}<0$ showed reaction (V) was spontaneous. This reaction consumed sulphuric acid originating from reaction I, as a result,coupling phenomenon between reaction reaction (I) and (V) promoted reaction (I) operating spontaneously. Integrate

$$
\mathrm{FeO}+\mathrm{CaSO}_{4}+2 \mathrm{HNO}_{3}=\mathrm{Ca}\left(\mathrm{NO}_{3}\right)_{2}+\mathrm{FeSO}_{4}+\mathrm{H}_{2} \mathrm{O}(\mathrm{VI})
$$

$\Delta \mathrm{G}_{298}^{\mathrm{o}}=-30.53 \mathrm{KJ}<0$ indicated reaction (IX) was spontaneous under ordinary temperature.

Side reactions: During disulphurization process, side reactions included (VI) and (VII) in theory. Reaction IX was advantageous to the main reaction and caused a little ferrous oxide dissolved. The thermodynamic analysis of Reaction (X) was as follows.

$$
\begin{array}{ccccc}
\mathrm{Fe}_{2} \mathrm{O}_{3}+6 \mathrm{HNO}_{3}=2 \mathrm{Fe}\left(\mathrm{NO}_{3}\right)_{3}+3 \mathrm{H}_{2} \mathrm{O} & (\mathrm{VII}) \\
\Delta_{\mathrm{f}} \mathrm{G}_{\mathrm{m}}^{\mathrm{o}} /(\mathrm{kJ} . \mathrm{mol}-1) & -741.53 & -110.58 & -338.16 & -237.19 \\
\Delta_{\mathrm{f}} \mathrm{H}_{\mathrm{m}}^{\mathrm{o}} /\left(\mathrm{kJ} \mathrm{mol}^{-1}\right) & -656.26 & -206.56 & -670.05 & -285.84 \\
\mathrm{~S}_{\mathrm{m}}^{\mathrm{o}} /\left(\mathrm{J} \mathrm{mol}^{-1} \mathrm{~K}^{-1}\right) & 87.32 & 146.4 & 123.31 & 69.94 \\
\Delta \mathrm{G}_{298}^{\mathrm{o}}=2 \times(-338.16)+3 \times(-237.19)-6 \times(-110.58)- \\
(-741.53)=17.12 \mathrm{~kJ} \mathrm{~mol}^{-1} \\
\Delta \mathrm{G}_{298}^{\mathrm{o}}>0 \text { showed reaction (VII) } \text { was not spontaneous. }
\end{array}
$$
In other words, ionic oxide would not be dissolved under the optimized conditions and remain in solid phase as iron ore concentrate.

Experiments under the optimized conditions: The reactions were conducted under the optimum conditions of temperature $50{ }^{\circ} \mathrm{C}$, reaction time $1 \mathrm{~h}$, excessive coefficient 15 and nitric acid concentration $5 \mathrm{~mol} \mathrm{~L}^{-1}$, and the XRD of obtained iron ore concentrate was shown in Fig. 6. In comparison with the XRD pattern of raw tailing (Fig. 1), Fig. 6 no longer indicated the presence of alumina, this effect attributed to the dissolution of alumina. Meanwhile, the peak of bassanite was not observed

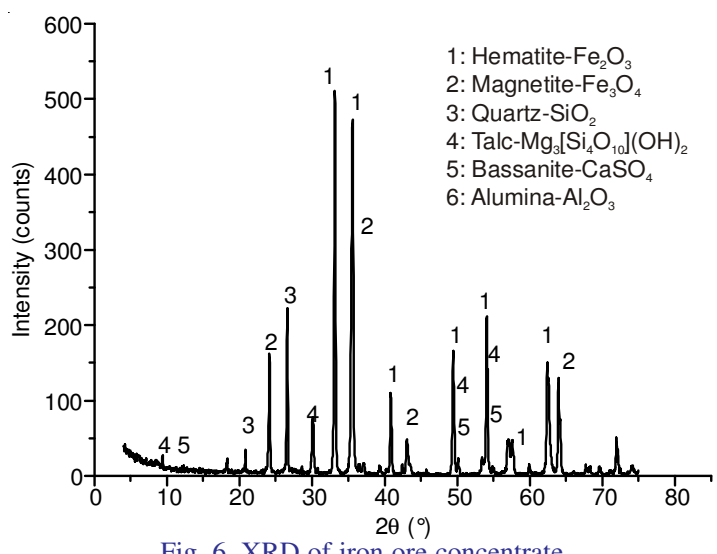

Fig. 6. XRD of iron ore concentrate and it could infer that nitric acid can markedly increase the solubility of calcium sulfate, which was consistent with the description above. In addition, the pattern of talc was weakened due to the dissolution of magnesium, whereas quartz still remained constant in solid phase.

Table- 4 indicated that the level of sulphur reduced to $0.03 \%$, meanwhile, the content of iron was added to $61.27 \%$ due to impurities being dissolved. In addition, the iron enrichment rate was $93 \%$.

\section{Conclusion}

Under the total process, three main parameters of iron oxide concentrate were obtained as the following: the total iron content of $61.27 \%$, and iron enrichment rate of $93 \%$. Furthermore, the sulphur content of product could be reduced to $0.03 \%$ and desulphurization rate is over $99 \%$.

After recycling iron from the leaching solution which pyrite cinder was treated with nitric acid, it would be utilized directly as raw mineral of nitro compound fertilizer. As a result, we can basically realize comprehensive utilization and zero emission of pyrite cinder waste. This process investigated presents some distinct advantages over aqua regia leaching technology on iron enrichment rate and leaching liquid comprehensive utilization. An economical and environmentally acceptable process for recovering iron oxide concentrate from highsulphur pyrite cinder has been successfully demonstrated with nitric acid leaching technology.

Certainly, it is necessary for low-grade pyrite cinder to raise iron oxide content. In general, when iron oxide content is less than $43 \%$, the way to decrease quartz content for increasing iron oxide content will be researched in the days to come.

\section{ACKNOWLEDGEMENTS}

This study was supported by the Educational Department of Henan province key scientific research project (13B610133). References

\section{REFERENCES}

1. R. Guan, D. Zhang and Q. Chen, China Mining Magazine, 20, 28 (2011).

2. N. Zhang, H. Sun, X. Liu and J. Zhang, J. Hazard. Mater., 167, 927 (2009).

3. K. Luke and E. Lachowski, J. Am. Ceram. Soc., 91, 4084 (2008).

4. D.Q. Tan and Y.J. Zheng, Chem. Eng., 34, 72 (2006).

5. I. Alp, H. Deveci, E.Y. Yazici, T. Türk and Y.H. Süngün, J. Hazard. Mater., 166, 144 (2009)

6. Z.Q. Gong, S. Gong, Z.B. Chen and B. Zhou, J. Cent. South Univ., 37, 703 (2006).

7. Y.J. Zheng and C. Peng, Acta Scient. Circumstant., 29, 1939 (2009).

8. C. Li, H. Sun, Z. Yi and L. Li, J. Hazard. Mater., 174, 78 (2010).

9. S.C. Lu, Minerals Flotation Foundation, Metallurgical Industry Press, Beijing (1988) (in Chinese).

10. S.K. Mandal and P.C. Banerjee, Int. J. Miner. Process., 74, 263 (2004).

11. B.B. He, X.K. Tian, Y. Sun, C. Yang, Y.L. Zeng, X. Wang, S.X. Zhang and Z.B. Pi, Hydrometallurgy, 104, 241 (2010).

12. A. Dutra, P. Paiva and L.M. Tavares, Miner. Eng., 19, 478 (2006).

13. Z.Z. Shi, A.Q. Gao and G.K. Zhang, Ind. Miner. Process., 10, 4 (2011).

14. S.X. Zhan and Y.J. Zheng, Chem. Eng., 34, 36 (2006)

15. S.H. Yang, M.T. Tang, K. Zhang and Y. Meng, J. Cent. South.Univ., 32, $583(2001)$ 